\title{
INFLUENCE OF EXPERIENTIAL MARKETING ON CUSTOMER LOYALTY IN SHARIAH-COMPLIANT HOTEL
}

\author{
Didin Samsudin $^{(1)}$, Fajar Kusnadi Kusumah Putra ${ }^{(2)^{*}}$ \\ (1) SMKN 1 Cipanas, Cianjur, West Java, Indonesia \\ (2) Sekolah Tinggi Pariwisata Bandung, West Java, Indonesia \\ didinsamsudin28.ds@gmail.com, fap@stp-bandung.ac.id
}

Submitted: 11 October 2019 Revised: 10 September 2020

Accepted: 29 September 2020

\begin{abstract}
This study set out to determine whether hotel guest perceptions in five aspects of experiential marketing: sense, feel, think, act, and relate and their effects on customer loyalty in Shariacompliant hotels. Quantitative research methods were used in this study, questionnaire assessments of experiential marketing and loyalty were collected from 100 respondents who stayed at Sharia-compliant hotels in the city of Jakarta, Indonesia. The findings show that experiential marketing was statistically significant $\left(R^{2}=0.677\right)$ as a predictor variable of customer loyalty in Sharia-compliant hotels.
\end{abstract}

Keywords: Shariah-compliant hotel, Experiential marketing, Customer loyalty, Islamic Hospitality.

\section{INTRODUCTION}

Halal tourism is one of the rising phenomena. According to the Global Muslim Travel Index (GMTI), the Muslim tourist market is expected to reach US\$ 220 billion in 2020. In 2017, there are 131 million Muslim tourists travelling around the world increased $8.2 \%$ from the previous period, the study also revealed that the Muslim tourism market will continue to grow rapidly (Mastercard Crescenrating, 2018).

In recent years, there has been increasing activities and facilities to support halal tourism. Demand for Shariah accommodation, halal food and beverages, transportation, and other sectors such as financial systems and halal holiday experiences (Jaelani, 2017; Widagdyo, 2015; Wingett \& Turnbull, 2017). According to Vargas-Sánchez and MoralMoral (2019), the core of halal tourism is emphasizing on the principles of Shariah, which has a series of implications in the provision of tourism services. In addition, they also mention three core of halal travelers needs in destination, first maximizing trip value based on culture benefits and experience; second halal travelers choose halal-friendly accommodation; third they choose family-friendly destinations.

As one of the core themes in halal travel, hotels and resorts must guarantee the "cultural comfort" of these travellers by providing basic facilities for prayer, cater halal food and beverages, and families and women-friendly facilities. The rise of Shariah-compliant hotels $(\mathrm{SCH})$ can be regarded as one key element of Islamic tourism especially for halal-friendly destinations, this type of business has a unique characteristic compared to conventional hotels. Shariah-compliant hotel main products are halal guarantee and creating experience both emotionally and religiously. Emotional and religious experience is expected to increase satisfaction from customers and 
ultimately will increase the loyalty of the guest (Razalli et al., 2013). Level of acceptance in Shariah-compliant hotel's concept highly depends on how the businesses integrating the existing hospitality concept and the Shariah rules, with pleasant experience and guarantee of spiritual experience as a Muslim (Idris \& Abdul Wahab, 2015; Mastercard Crescenrating, 2018).

Based on research conducted by Mastercard Crescenrating (2018) on the Global Muslim Travel Index, Indonesia ranked second in the world's halal tourism destination. Indonesia has been nominated and won 12 of the 16 existing nominations in 2016 World Halal Tourism Award. Indonesia entitled with the prestigious award as the best halal destination in the world and fort the accommodation sector category World's Best Halal Beach Resort, World's Best Family Friendly Hotel and World's Most Luxurious Family Friendly Hotel (Indonesia Travel, 2018). However, the development of Shariahcompliant hotels especially in Indonesia is still dawdling.

The issue has grown in the importance of halal tourism, especially in Indonesia. Shariah-compliant hotel expected to promote their products and services for both Muslim and non-Muslim guest who have demand on halal lifestyle, family-friendly place and culturally more enriching experience (Ridzuan \& Zahari, 2012b). Customer enjoyment often specifically helps the consumers to carry out the purchasing process by focusing on the value of the product (Andreani, 2009). The previous study has highlighted customer awareness, marketing and promotion in Shariah-compliant hotel (Ozdemir \& Met, 2012; Ridzuan \& Zahari, 2012a). Debate continues about the best strategies for the management of Shariahcompliant hotel to implement more rational and emotional related to experiential marketing, in order to gain valuable experience and consumed the products and services offered repeatedly (Schmitt, 1999).
However, there is no single study exists which systematically investigate and assessing the experiential value obtained by hotel customers affecting guest loyalty in the context of Shariah-compliant hotel. Therefore, the primary aim of this paper is to understand the perceived value of experiential marketing towards loyalty in Shariahcompliant hotel. Specifically, the following issues will be addressed: First to explore the influential degrees of experiential marketing dimensions in shariah-compliant hotel; secondly to examine how the five dimensions of experiential marketing predict the guest loyalty within the context of Shariahcompliant hotel.

\section{LITERATURE REVIEW}

\section{Experiential Marketing}

Pine and Gilmore (1998), first introduced experiential marketing as part of their work in the experience economy. According to their research, experiential marketing is a contemporary view in delivering the message for the customer about product and service by focus on the quality of physical and real interactive experiences. This approach is relatively different compared to traditional views in marketing to expose the product by using advertising media such as print or electronic messaging. There are five elements of experiential marketing in assessing customer experience, which our senses, feelings, thoughts, actions and social relationships (Andreani, 2009; Kartajaya, 2006; Palupi, 2001; Smilansky, 2017).

A broader perspective has been adopted by Andreani (2009) who argues that experiential marketing is more than just providing opportunities for customers to gain emotional experience and rational in consuming products or service. There are several goals that can be achieved by a marketer in involving customers feelings and emotions, very often this emotional aspect provides effective impact in the marketing process in selling products or delivering services and at the end to enhance the brand awareness, brand equity and customer loyalty. 

Customer Loyalty in Shariah-Compliant Hotel

Schmitt (1999) suggests that emotional aspects should be inspiring and attract customers to try new things, do different things, change themselves for a better life, and create a connection between customers individually and with society or culture. He also points out the key of success of the experiential marketing is focus on customer experiences, consumption as a holistic experience, customers are emotionally as well as rationally driven, and strategy from experiential marketer are diverse and multifaceted. Moreover, Schmitt (1999) also describe two approaches in experiential marketing, namely Strategic Experiential Modules (SMEs) and Experiential Providers (ExPros). The approach through SEMs emphasizes more on the aspect of senses, feel, think, act, and relate. While ExPros are supporting elements in SEMs such as communication, visually identify, product presence, co-branding, spatial environment, website, and people.

The interactive experience based on SMEs is related to each other. First, to stimulate customer senses there are several marketing strategies namely: five senses as a differentiator, five senses as a motivator, and value provider (Andreani, 2009; Schmitt, 1999). Moreover, Putri and Astuti (2012) explained that senses are tangible products, it can be felt by the five human senses such as sight, smell, taste, hearing, and touch. The function of this sense is to differentiate a product from other products, motivate purchase decision, and shape customer ratings at the end the overall satisfaction for the products.

The second dimensions are Feel which has a close relationship with the emotions of customers. One of the examples is the creation of service environment which is more intangible aspect and depend on the skill, knowledge and attitude of the staff to deliver the services and products and at the same time create relationships with the consumer. What customers feel then will follow up with think dimensions related to problem-solving experience. Companies try to challenge customers and at the same time encourage customers to interact creatively and cognitively in the product creation stage, this stage is part of the innovation process. Moreover, companies will provide information and communicate their product through various media and through internal marketing through the quality of services provide by staff in order to make customers think and conclude on their own whether they will buy the products or not.

After the decisions process then the customer will act, this is an action that relates to a person (mind and body) to meet the needs of life and lifestyle. Through spending their money to consumed products and enjoying services and satisfy their needs. Schmitt (1999) suggest attraction to give customers self-improvement, economically and social status identified by personal brands choice. To achieve this objective, previous aspects sense, feel, think, act should relate to each other.

Therefore, the experience of influencing consumers will be focus on creating positive perceptions for the consumers. Collectively, these studies outline a critical role in the experiential marketing approach to maintain business by using a combination marketing strategy and providing a valuable emotional experience. To conclude Schmitt (1999) has mentioned the strategic experience modules composed of consumers' 5 various experience types, namely sensation experience, emotion experience, thinking experience, action experience and association experience.

In the field of tourism, research on experiential marketing to improve customer experience and customer loyalty are carried out in a number of contexts, such as those carried out in travel agent company (Jatmiko \& Andharini, 2012). Some authors have mainly been interested in question concerning tourist attractions, for example, zoo, hot springs resort, and historic heritage sites (Lin et al., 2009; Tsaur et al., 2007; H.-C. Wu \& $\mathrm{Li}, 2017)$. In the context of services and guest loyalty in restaurant and hotel sectors, some authors found that environmental factors and interactions with service employees and other 
consumers positively influence the consumer experiential value (Noegroho, 2013; Putri \& Astuti, 2012; C. H.-J. Wu \& Liang, 2009). Specific on Islamic experiential marketing study has been conducted to assess the application of Islamic experiential marketing value in the retail business sector (Aziz et al., 2016). However, such studies remain narrow in focus dealing only with more retail products only. This review has demonstrated the shortcomings of Islamic marketing in the context of tourism sectors, especially in Shariah-compliant hotel business.

\section{Shariah-Compliant Hotel (SCH)}

Definition of Shariah-compliant hotel is accommodation service adheres to the principles of Islamic teaching guidelines and provide Islamic atmosphere with unique characteristics that have consequences for their development, management and marketing (Basalamah, 2011; Fitriani, 2018; Henderson, 2010). Shariah-compliant hotel businesses need to take a holistic approach and practice in operations accordingly to obtain Shariah hotel certification and Halal label to maintain the customer perceptions and assurance related to their products and services (Henderson, 2016; Samori \& Rahman, 2013; Samori \& Sabtu, 2014).

In previous studies, dimensions of Shariah-compliant hotels related to reception, employees, room facilities, halal food and beverage facilities, praying facilities, and other facilities i.e. halal shop (Ridzuan \& Zahari, 2012b; Salleh et al., 2014). There are principles different between Shariahcompliant hotel and conventional hotel, Idris and Abdul Wahab (2015) stated that most of the Shariah-compliant hotel operation ranging from room design, food and beverages, housekeeping, workers uniform, and other facilities offered to the guest. A recent study by Karim, Ahmad, and Zainol (2017) involved management and administration aspects of an Islamic hotel also play an

\footnotetext{
${ }^{1}$ Akhlaq in english is disposition, nature, temper, ethics, morals or manners (of a person).
}

important role in addition to the operational aspects. Management aspects such as providing daily routine of Shariah-compliant manager guidance, Islamic financial aspect, and Islamic promotion material. They also highlighted the Islamic management in trained their staff with $A k h l a q^{1}$, religious activities and events i.e. Al-Quran and Yassin recitation.

Shariah-compliant hotel classifications apply in some Muslim countries. In Malaysia standardisation is based on Malaysian Halal Standards for the quality management system and Halal food management, and the halal certification will be issued by Jabatan Kemajuan Islam Malaysia (JAKIM) (Karim et al., 2017; Salleh et al., 2014). In the Middle East and North Africa (MENA) region the concept of Shariah-compliant hotel is based on three aspects operation, design and financial, moreover there are challenges faced by the hotel to fully adapted Shariahcompliant hotel concept related to hotel enterprise, human resources, and guests (Saad $\&$ Ali, 2014). There are some basic requirements for the Shariah-compliant hotel's standardization process based on the characteristics of products, services, and management can be seen in table 1 .

In case of Indonesia Shariah-compliant hotel, Indonesian government through the Ministry of Tourism in cooperation with DSN-MUI creating guidance for the certification process and the issuance of Shariah hotel certificates (Peraturan Menteri Pariwisata \& Ekonomi Kreatif Nomor.2 Tahun 2014: Tentang Pedoman Penyelenggaraan Usaha Hotel Syariah, 2014).

The certification is based on the categories of Hilal-1 consist of 49 subelements: 27 products, 20 services, and 2 management. For Hilal-2 consist of 74 subelements: 40 products, 28 services and 6 management (the complete list can be seen in Appendix 1). Hilal categorization aims to provide guidance on the implementation of

\footnotetext{
"Disposition" is a faculty (malakah) of the soul (nafs) which unconsciously inspires activities.
} 
Sharia rules. Hoteliers who have not yet received a Shariah hotel business certificate issued by DSN-MUI but have organized and/or postulated themselves as a Shariah hotel business at the should adjust their operations according to the regulation (Peraturan Menteri Pariwisata \& Ekonomi Kreatif Nomor.2 Tahun 2014: Tentang Pedoman Penyelenggaraan Usaha Hotel Syariah, 2014; Permana W, 2018).

\section{Customer Loyalty}

Definition of loyalty is a pleasant attitude towards a product or brand that is offered then make a consistent purchase of the brand repeatedly. Thus the loyalty of one loyal consumer behaviour and make purchases of certain brands repeatedly (Sumarwan, 2011).

The loyal definition not only in the company's products and services but also the overall portfolio of company products and services as part of the loyalty life brand (Gaffar, 2007). According to Griffin (2005), the concept of loyalty is more directed towards behaviour compared to attitude and a loyal customer will show long-term buying behaviour, which is carried out by decisionmaking units.

Shoemaker and Lewis (1999) explained that loyalty marketing or retention marketing is needed so that the business can be successful in the future. It is also explained by Hassan, Pourabedin, Sade, and Chai (2018) in the context of hotel business, how the strength of the perceived value indirectly stimulates customer's loyalty to a hotel, followed by the interaction and economic value from the customer value perspective to ensure customer's loyalty.

In addition, research conducted by Jani and Han (2014) mention that hoteliers must concentrate their efforts on satisfying guests in order to create loyalty and improve hotel image for their guests. However, Cetin and Dincer (2014) are more concerned with customer experience, and how positive experiences affect customer behaviour. The studies presented thus far provide evidence that loyalty indicated by making re-purchase intention, buying between product lines and services, recommending to others, positive oral administration, and showing immunity to move to other products over by competitors.

\section{RESEARCH METHOD \\ Data collection}

This study was conducted using a quantitative approach and empirical research. This study used the questionnaire survey as the main method for the collection of data. Data were collected by using non-probability sampling to 130 local guest who stay at one of the sharia-compliant hotels in Jakarta, Indonesia. The questionnaire was distributed to guests (respondents) between May - June 2017. The questionnaire distributed are in Bahasa and consisting of 34 questions divided into three sections.

Table 1. Dimensions of Shariah-compliant Hotel in Other Countries Dimensions Description

\begin{tabular}{|c|c|}
\hline Dimensions & Description \\
\hline Reception & $\begin{array}{l}\text { - Islamic Music background (nasyeed or Al-Quran recitation) } \\
\text { and Azan } \\
\text { - } \quad \text { Disallowed non-married couples to stay in the same room } \\
\text { - Hotel staff have been trained to identify married couples and } \\
\text { not married, and do not hesitate to reprimand guests who } \\
\text { bring partners not mahram }\end{array}$ \\
\hline
\end{tabular}

\footnotetext{
${ }^{2}$ Mahram is unmarriageable kin with whom marriage or sexual intercourse would be considered haram, illegal in Islam, or people from whom purdah is not obligatory or legal escorts of a woman during journey longer than a day and night, 24 hours.
}

\footnotetext{
${ }^{3}$ Awrah refers to anything which can be easily harmed just like a bare or exposed place. Therefore it becomes clear that the body of a woman is referred to as vulnerable because it is like a house which contains no walls and can be easily harmed and must be covered with the appropriate clothing (Majma' Al Bian, Commentary upon the Quran, 33:14.\#2312).
} 


\begin{tabular}{|c|c|}
\hline Employees & $\begin{array}{l}\text { - } \quad \text { Most of the staff are Muslim } \\
\text { - } \quad \text { All-female staff is required to wear the hijab } \\
\text { - } \quad \text { Greet and receive guests with the Islamic greeting }\end{array}$ \\
\hline $\begin{array}{l}\text { Room } \\
\text { Facilities }\end{array}$ & $\begin{array}{l}\text { - Different allocation room for each consumer by gender (i.e. } \\
\text { single women floor with women housekeeper; single male } \\
\text { floor with a male housekeeper) } \\
\text { - } \quad \text { Designated floor for families } \\
\text { - } \quad \text { Spacious bedrooms for Muslim guest perform their prayer } \\
\text { - } \quad \text { Rooms decoration should not depict the human and animal } \\
\text { form } \\
\text { - } \quad \text { Bed and toilet cannot be placed facing the direction of } \\
\text { Makkah } \\
\text { - Printed information of nearby mosque, halal restaurant, and } \\
\text { other groceries } \\
\text { In-room Al-Quran, prayer mat, qibla sign, prayer schedule }\end{array}$ \\
\hline $\begin{array}{l}\text { Food } \\
\text { and } \\
\text { Beverage } \\
\text { Services }\end{array}$ & $\begin{array}{ll}\text { - } & \text { Halal certificate for all food and beverage outlets } \\
\text { - } & \text { No alcoholic beverages and non-halal food (e.g., pork, lard) } \\
\text { - } & \text { Providing Sahur and Iftar }{ }^{4} \text { buffet in Ramadhan month }\end{array}$ \\
\hline $\begin{array}{l}\text { Toilet } \\
\text { facilities }\end{array}$ & $\begin{array}{l}\text { Providing enough water or shower toilets to make it easier to } \\
\text { wash after using the toilet (i.e. providing bidet/gun sprayer) }\end{array}$ \\
\hline $\begin{array}{l}\text { Reminder } \\
\text { for } \\
\text { worship } \\
\text { time }\end{array}$ & $\begin{array}{l}\text { - Provides alarm facilities for prayer times, located in a private } \\
\text { place such as guest rooms and public places. } \\
\text { - } \\
\text { Religious event (Al-Quran and } \text { Yaseen }^{5} \text { recitation, } \text { tazkirah }^{6} \text { or } \\
\text { qiamullail }^{7} \text { ) }\end{array}$ \\
\hline $\begin{array}{l}\text { Other } \\
\text { Facilities }\end{array}$ & $\begin{array}{ll}\text { - } & \text { Provide fitness facilities that have separated room for women } \\
\text { and men } & \\
\text { - } & \text { Separate swimming pool for male, female, and family } \\
\text { - } & \text { Meeting rooms and spacious Banquet room to cater separate } \\
\text { seating arrangement for both male and female } \\
\text { - } \quad \text { No red-light entertainment (night club, disco, karaoke) } \\
\text { - } \quad \text { Halal-friendly activities for family and children } \\
\text { - } \quad \text { Shop selling Halal and Islamic related products } \\
\text { - Separate prayer rooms for male and female and accompanied } \\
\text { with qibla sign }\end{array}$ \\
\hline Management & $\begin{array}{ll}\text { - } & \text { Everyday routine with Shariah-compliant manager guidance } \\
\text { - } & \text { Appointed Shariah-compliant manager } \\
\text { - } & \text { Islamic financed management with follow } z a k a t^{8} \text { principles } \\
\text { - } & \text { Ethical promotional activities (absence of sexual appeal and } \\
\text { manipulation) }\end{array}$ \\
\hline
\end{tabular}

Sources: Henderson, 2010; Ridzuan \& Zahari, 2012b; Saad \& Ali, 2014; Salleh et al., 2014

${ }^{4}$ Iftar (Arabic: إفطار, lit. 'break of a fast'), also known as fatoor (from فطور fuṭūr 'breakfast'), is the evening meal with which Muslims end their daily Ramadan fast at sunset.

${ }^{5}$ Yaseen (Arabic: بس) is the 36th sürah of the Quran. It has 83 verses (āyāt). Regarding the timing and contextual background of the supposed revelation.

${ }^{6}$ Tazkirah (تذكرة) is an Arabic term for "memorandum" or "admonition". It is frequently used as part of the title of literary works of the nature of authoritative collections or summaries.

${ }^{7}$ Qiamullail refers to the practice of worship at night by practicing circumcision prayers such as salat Tahajjud.

${ }^{8}$ Zakat (Arabic: زكاة), "that which purifies", is a form of almsgiving treated in Islam as a religious obligation or tax, which, by Quranic ranking, is next after prayer (salat) in importance. 


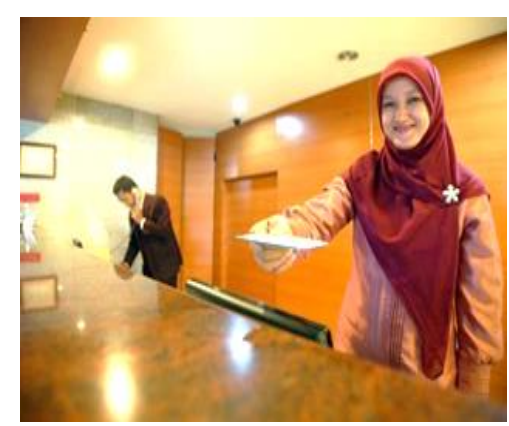

(a)

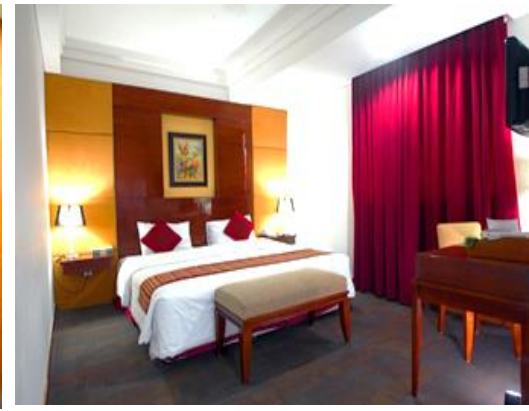

(b)

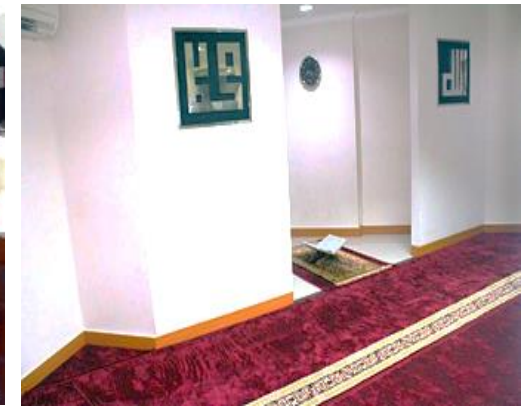

(c)

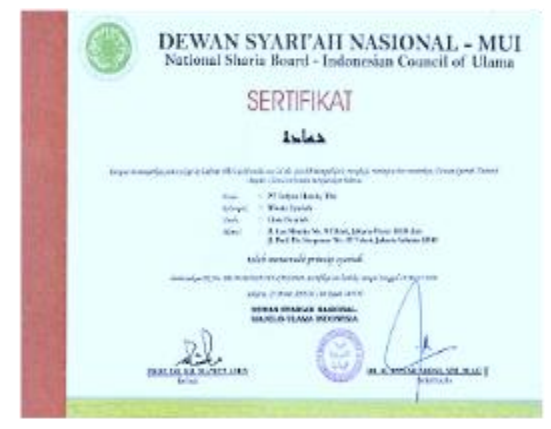

(d)

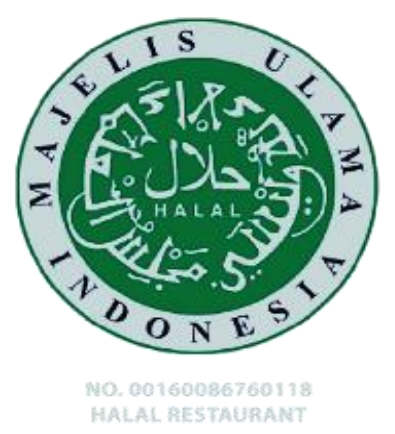

(e)

Figure 1. Shariah-Compliant Hotel

(a) Front liner staff; (b) Bedroom; (c) Prayer room; (d) Shariah-compliant hotel certificate;

(e) DSN-MUI, Halal certificate logo

Source: Sofyan Hotel, 2019

In the first section of the questionnaire, the guest was asked to express their overall perception of Shariah-compliant hotel. For the experiential marketing sections, all the questionnaire was developed from Strategic Experiential Modules (SMEs) theory (Schmitt, 1999), with some modification to Shariah-compliant hotel product and services. In total there are 20 questions in the first section of the questionnaire consist of five dimensions namely senses (four items), feel (four items), think (four items), act (four items), relate (four items).

The second section, participants were asked to express their loyalty level regarding the repurchase intention, buying the product and services, recommend to others based on a 5-point Likert scale, from "Strongly disagree" to "Strongly agree". The questionnaire using a 5-point Likert scale from "Strongly disagree" to "Strongly agree". The 5-point Likert scale captures more variances than a binary scale of yes or no (Lehto, Lin, Chen, \& Choi, 2012) and is most frequently utilized to measure the intensity of a single attribute (Mazzocchi, 2008). In this study, by adopting 5-point Likert scales in different sections, researchers can be assisted with a better understanding of participants' perceptions, satisfaction levels, as well as revisit intention. The respondents further asked to express their disagreement or agreement of loyalty and level of priority to stay in Shariah-compliant hotel based on a 5-point Likert scale for the customer loyalty dimensions the framework is based on Griffin (2005), consist of eight questions repurchase intention (two items), product buying line and service (two items), recommendation to others (two items) and immunity to competitor offers (two items). In 
the third section, demographics information including gender, education level, occupation, age as well as the travel companion, and their origin was asked, and consent form regarding respondents' participation in this research was also explained.

Table 2. Respondents Profile $(\mathbf{n}=100)$

\begin{tabular}{lrrr}
\hline Variables & Category & N & $\%$ \\
\hline Gender & $\begin{array}{r}\text { Male } \\
\text { Fge }\end{array}$ & 61 & $61 \%$ \\
& & 39 & $39 \%$ \\
& $18-23$ & 23 & $23 \%$ \\
& $24-30$ & 29 & $29 \%$ \\
& $31-40$ & 37 & $37 \%$ \\
& $41-50$ & 4 & $4 \%$ \\
\multicolumn{2}{c}{ Female } \\
\multicolumn{2}{c}{ Above $>60$ years old } & 2 & $2 \%$
\end{tabular}

Education level

$\begin{array}{rcc}\text { High School } & 21 & 21 \% \\ \text { Graduate } & 64 & 64 \% \\ \text { Postgraduate } & 15 & 15 \% \\ \text { Area of origin } & & \\ \text { Jakarta } & 32 & 32 \% \\ \text { Bandung } & 27 & 27 \% \\ \text { Banten } & 16 & 16 \% \\ \text { Bogor } & 13 & 13 \% \\ \text { Others } & 12 & 12 \% \\ \text { Travel companion } & & \\ \text { Individual travel } & 31 & 31 \% \\ \text { Friends } & 15 & 15 \% \\ \text { Family } & 38 & 38 \% \\ \text { Husband/wife } & 8 & 8 \% \\ \text { Co-workers } & 8 & 8 \% \\ \text { Number of Visit to } & & \\ \text { Sharia-compliant hotel } & & 72 \% \\ \text { First time } & 72 & 26 \% \\ 2-5 \text { times } & 26 & 2 \% \\ \text { More than 5 times } & 2 & \end{array}$

Out of a total of 130 questionnaires that were collected, only 100 were fit to be used for further evaluation. The survey was completed by 100 respondents who met the criterion selection which required that participants who are stayed at Shariahcompliant hotel. Table 2 shows the demographic characteristics of the respondents. The sample was slightly male dominated $(61 \%)$, the majority were millennials with age ranging from years 18-30 years old (52\%). Most of the respondents are holding undergraduate education (64\%). Majority of the guest who participates and stays at Shariah-compliant hotel are come with their family $(38 \%)$, and only with their husband/wife (8\%). Since the location of the hotel in Jakarta, most of the respondents came from Jakarta, Bogor and Banten area (61\%). Interestingly, most of the guests (72\%) make their first visit to Shariah-compliant hotel, with only $2 \%$ of them has visited more than five times.

\section{Data analysis}

Data were analysed in SPSS 23.0 for Windows (Aldrich, 2018). There are two analysis used for this study First, descriptive statistics were used to profile the demographics of the participants and the general perception of Shariah-compliant hotel guest. Secondly, respondents were asked questions in relation to their perception of experiential marketing in Shariah-compliant hotel by ranking how their experiences with five dimensions of senses, feel, think, act, and relate (see table 3 ).

\section{RESULT AND DISCUSSION \\ Experiential Marketing}

Senses

From the first dimension senses were associated with four items stimulated the human senses of sight, smell, taste, hearing, and touch (Putri \& Astuti, 2012). In overall, this component (mean=3.95) represent by interior design, food and beverages, temperature and lighting, and bedroom aroma. There was a high level of agreement among the respondents that Halal food and drinks are offered in the hotel are tasty (mean $=4.38$ ).

Feel

The second dimension feel (mean=4.11), the respondents were slightly agreeing that Shariah-compliant hotel provides security and Islamic hospitality feel. With the highest score on a sense of security (mean=4.29). Respondents are also agreed 
with another two factors such as staff sharia appearance and the comfort in the room has given an more feel staying at sharia compliant hotel.

\section{Think}

For the third dimension think, finding showed that respondents slightly agree (mean=3.86) with how halal product innovation being communicate, however respondents perceived neutral the promotion of room.

\section{Act}

The fourth-dimension act components mostly of respondents are agreeing about the level of services (mean=3.93), they perceived that Shariah-hotel is very useful and the rooms are easy to be booked. They also agree that the price level is in line with services that has been deliver according to the customer needs.

\section{Relate}

The last dimension is related to valuable experience in sharia compliant hotel with the indicator of staff friendliness, guest prestige, and ease of use of electronic media (mean=3.84). However, respondents still perceived neutral for Shariah-compliant hotel as an indication of their prestige.

\section{Customer Loyalty}

The results also showed us that all variables in customer loyalty relatively neutral or slightly agreeing (mean=3.64-4.05) repurchase intention, choosing, recommend and loyal with Shariah-compliant hotel. The highest value for the loyalty indicator is the desire of guests to stay back at Shariah Hotel with an average value of 4.05 . for the lowest average value recorded by Shariah-compliant hotel, products and services are a priority with an average of 3.64.

\section{Table 3. Measurement Items for Five Dimensions in Experiential Marketing for Sharia Compliant Hotel}

\begin{tabular}{|c|c|c|c|}
\hline Dimensions & Items & Mean & $\begin{array}{c}\text { Std. } \\
\text { Deviation }\end{array}$ \\
\hline \multirow[t]{4}{*}{ Sense } & - Interior design according to sharia & 3.84 & .884 \\
\hline & - Halal food and drinks & 4.38 & .775 \\
\hline & - Room temperature and lighting & 3.85 & .808 \\
\hline & - Bedroom aroma & 3.73 & .851 \\
\hline \multirow[t]{4}{*}{ Feel } & - The appearance of staff complies to sharia & 4.00 & .804 \\
\hline & • Islamic hospitality & 4.25 & .845 \\
\hline & - Comfort in the room & 3.93 & .956 \\
\hline & - Sharia Hotel provides a sense of security & 4.29 & .624 \\
\hline \multirow[t]{4}{*}{ Think } & - Halal product innovation & 4.01 & .797 \\
\hline & - Promotion of room sales & 3.57 & .977 \\
\hline & - Communicative Sharia Hotel Advertisements & 3.91 & .922 \\
\hline & - Staff shows/reflects the quality of Sharia Hotel & 3.97 & .797 \\
\hline \multirow[t]{4}{*}{ Act } & - Ease of obtaining rooms & 4.02 & .778 \\
\hline & - Services according to needs & 3.88 & .879 \\
\hline & - Price level & 3.80 & .724 \\
\hline & - Sharia Hotel is very useful & 4.03 & .869 \\
\hline \multirow[t]{4}{*}{ Relate } & - Sharia Hotel for guest prestige & 3.44 & 1,122 \\
\hline & - Staff relations with hotel guests & 3.98 & .791 \\
\hline & - Easy use of electronic media & 3.88 & .794 \\
\hline & - Providing valuable experience & 4.07 & .934 \\
\hline Repurchase intention & - Willing to return to Sharia Hotel & 4.05 & .757 \\
\hline
\end{tabular}


- Hold Meeting / events in Sharia Hotel

Buying delivery of

- Accommodation that I choose is a pioneer in Sharia

product and service

Hotel

- Reliability on Sharia Hotels that I choose

$4.02 \quad .828$

Recommend to others

- Willing to recommend to relatives/friends

Showing resilience to

-Willing to recommend on personal social media

Note: Experiential marketing and customer loyalty measured by 5 -point scale ranging from $1=$ Strongly disagree, $2=$ Disagree, $3=$ Neutral, 4=Agree, $5=$ Strongly agree

Table 4. Descriptive Statistics

\begin{tabular}{cc|r|c}
\hline & Mean & $\begin{array}{c}\text { Std. } \\
\text { Deviation }\end{array}$ & \multicolumn{1}{c}{$\mathrm{N}$} \\
\hline $\begin{array}{c}\text { Customer } \\
\text { Loyalty }\end{array}$ & 3.8688 & .15579 & 100 \\
\hline $\begin{array}{c}\text { Experiential } \\
\text { Marketing }\end{array}$ & 3.9415 & .22141 & 100 \\
\hline
\end{tabular}

Table 5. Model Summary

\begin{tabular}{|c|c|c|c|c|c|}
\hline Model & $\mathrm{R}$ & $\begin{array}{c}\mathrm{R} \\
\text { Square }\end{array}$ & $\begin{array}{c}\text { Adjusted } \\
\text { R } \\
\text { Square }\end{array}$ & $\begin{array}{l}\text { Std. } \\
\text { Error } \\
\text { of } \\
\text { the } \\
\text { Estimate }\end{array}$ & $\begin{array}{c}\mathrm{R} \\
\text { Square } \\
\text { Change }\end{array}$ \\
\hline 1 & $.823^{\mathrm{a}}$ & .677 & .674 & 2.9153 & .674 \\
\hline
\end{tabular}

a. Predictors: (Constant), Experiential Marketing b. Dependent Variable: Customer Loyalty

From table 5, $\mathrm{R}$ represents the multiple correlations because there is only one predictor variable with $\mathrm{R}$-value (.823). $\mathrm{R}$ Square is the squared multiple correlations and represents the strength of the predictive relationship here, its value is .677 (the Pearson $r^{2}$ ) and suggests that about $67.7 \%$ of the variance of customer loyalty is explained by experiential marketing.

While the other $32.3 \%$ is explained by another variance. Adjusted $\mathrm{R}^{2}$, which accounts for the number of explanatory variables in relation to the number of observations and number of parameters, is also computed to be .674 .

Table 6. Coefficients ${ }^{\mathrm{a}}$

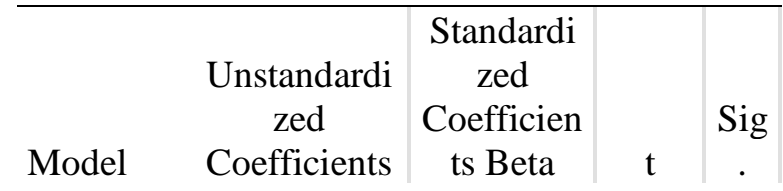

\begin{tabular}{rr|r|r|r|r}
\hline (Constant) & 3.526 & 1.93 & & 1.82 & .07 \\
\hline $\begin{array}{r}\text { Experient } \\
\text { ial }\end{array}$ & & & & & \\
Marketin & & & & & \\
$\mathrm{g}$ & .348 & .024 & .823 & 44.3 & .00 \\
\hline
\end{tabular}

a. Dependent Variable: Customer Loyalty b. Predictors: (Constant), Experiential Marketing

Table 6 presents the Coefficients of the variable in the regression model, the unstandardized (raw score) regression coefficient for experiential marketing is .348 (this is the slope of the unstandardized model) and is statistically significant $(\mathrm{p}<.001)$ as assessed by a t-test.

Because it is positive, we can say that an increase of one unit on the experiential marketing measure is expected to be associated with an increase in customer loyalty value of 0.348 units. This may seem like a small increase in customer loyalty until we recall (Table 4) that experiential marketing scores average about 3.9415 and customer loyalty scores average about 3.8688 .

The beta (standardized) regression coefficient for Experiential marketing is .823; this is also the value of the Pearson $r$ between Experiential Marketing and Customer loyalty.

Based on the value of this coefficient, we can say that an increase of $1.00 \mathrm{z}$ score (one standard deviation unit) on the Experiential marketing measure is expected to be associated with an increase in Customer loyalty of $.823 \mathrm{z}$ score (standard deviation) units. 


\section{CONCLUSION}

This study has found the assessment of guests staying on loyalty to Shariah Hotel is based on an analysis of the four dimensions of making regular purchases, buying between product lines and services, referring to others and showing immunity to move from competitor pull is in the sufficient category. Simultaneously, there is a positive and significant influence of experiential marketing on guest loyalty in Shariah Hotel. Collectively, these studies outline a critical role for that experiential marketing approach is an experience of products, services and brands to increase the level of sales and ultimately brand image, and customer loyalty wherein its implementation can provide an opportunity to be able to increase the level of emotions and feelings of the customers in Shariah-compliant hotel. Experiential marketing can be used to increase consumer loyalty if the performance of services and product offered, can satisfy guests expectations, and provide valuable experience. Halal tourism is affected by tourists religiosity, which is evidenced by their awareness and application of Islamic preaching in their daily lives and also unforgettable encounters when experiencing events and attractions in destinations (Amalia \& Yahya, 2018).

To increase guest loyalty to Shariahcompliant hotel, it is necessary to evaluate and improve the quality of products, services by the management based on the Hilal categorisation and DSN-MUI halal standard (Permana, 2018). Accommodation of Muslim Friendly needs to pay attention to the hospitality of the staff who becomes the image of the hotel their standard appearance that conforms to Islamic law and attitudes to service will provide marketing stimulation more optimal. With the slightly neutral value on the immunity against other products from competitors, provides evidence that there should be more effort to increase customer loyalty towards Shariah-compliant hotel products and services. In the future, research can be conducted by examining more number in samples, comparing with different category of Shariah-compliant hotels, as well as more extensive operational area coverage both in Indonesia and in other countries.

\section{REFERENCES}

Aldrich, J. O. (2018). Using IBM® SPSS® Statistics: An interactive hands-on approach. Sage Publications.

Amalia, R., \& Yahya, A. (2018). Halal tourism: Analysis of Religiosity, MTES and revisit intentions. PEOPLE: International Journal of Social Sciences, 4(3), 1056-1068.

Andreani, F. (2009). Experiential marketing (sebuah pendekatan pemasaran). Jurnal Manajemen Pemasaran, 2(1), 1-8.

Aziz, S. A., Musa, R., \& Rahman, S. A. (2016). Theorizing Islamic retail experiential value in predicting total Islamic experience quality: a hypothesised model. Procedia Economics and Finance, 37(2016), 453459.

Basalamah, A. (2011). Hadirnya kemasan syariah dalam bisnis perhotelan di tanah air. Binus Business Review, 2(2), 763769.

Cetin, G., \& Dincer, F. I. (2014). Influence of customer experience on loyalty and word-of-mouth in hospitality operations. Anatolia, 25(2), 181-194.

Fitriani, H. (2018). Proyeksi Potensi Pengembangan Pariwisata Perhotelan Dengan Konsep Syariah. Muslim Heritage, 3(1), 45-66.

Gaffar, V. (2007). Customer Relationship Management and Marketing Public Relation. Bandung: Alfabeta.

Griffin, J. (2005). Customer Loyalty: How to Keep it, How to earn it. Edisi Revisi, Bahasa Indonesia, Jakarta: Erlangga.

Hassan, H., Pourabedin, Z., Sade, A. B., \& Chai, J. (2018). Loyalty membership for luxury hotels in Malaysia. International Journal of Tourism Cities, 4(2), 179193.

Henderson, J. C. (2010). Sharia-compliant hotels. Tourism and Hospitality 
Research, 10(3), 246-254.

Henderson, J. C. (2016). Halal food, certification and halal tourism: Insights from Malaysia and Singapore. Tourism Management Perspectives, 19(Part B, July), 160-164.

Idris, J., \& Abdul Wahab, N. (2015). The competitive advantages of Shariacompliant hotel concept in Malaysia: SWOT analysis. Proceeding of the 2nd International Conference on Management and Muamalah 2015 (2nd ICoMM), 200-209.

Indonesia Travel. (2018). Indonesia Dominates World Halal Tourism Awards 2016 Winning 12 Top Categories. https://www.indonesia.travel/gb/en/new s/indonesia-dominates-world-halaltourism-awards-2016-winning-12-topcategories

Jaelani, A. (2017). Halal tourism industry in Indonesia: Potential and prospects. International Review of Management and Marketing, 7(3), 25-34.

Jani, D., \& Han, H. (2014). Personality, satisfaction, image, ambience, and loyalty: Testing their relationships in the hotel industry. International Journal of Hospitality Management, 37(February), 11-20.

Jatmiko, R. D., \& Andharini, S. N. (2012). Analisis experiential marketing dan loyalitas pelanggan jasa wisata (Studi pada Taman Rekreasi Sengkaling Malang). Jurnal Manajemen Dan Kewirausahaan, 14(2), 128-137.

Karim, M. H. A., Ahmad, R., \& Zainol, N. A. (2017). Differences in hotel attributes: Islamic hotel and Sharia compliant hotel in Malaysia. Journal of Global Business and Social Entrepreneurship, 1(2), 157169.

Kartajaya, H. (2006). Hermawan Kartajaya on Marketing Mix Seri 9 Elemen Marketing. PT. Mizan Pustaka.

Peraturan Menteri Pariwisata \& Ekonomi Kreatif Nomor.2 Tahun 2014: Tentang Pedoman Penyelenggaraan Usaha Hotel Syariah, (2014).
Lin, K.-M., Chang, C.-M., Lin, Z.-P., Tseng, M.-L., \& Lan, L. W. (2009). Application of experiential marketing strategy to identify factors affecting guests' leisure behaviour in Taiwan hot-spring hotel. WSEAS Transactions on Business and Economics, 6(5), 229-240.

Mastercard Crescenrating. (2018). Global Muslim Travel Index 2018. https://www.crescentrating.com/reports/ mastercard-crescentrating-globalmuslim-travel-index-gmti-2018.html.

Noegroho, O. A. (2013). Pengaruh Experiential Marketing Dan Brand Trust Terhadap Kepuasan Pelanggan Dan Loyalitas Pelanggan (Survei Pada Pelanggan Kfc Cabang Kawi Malang). Jurnal Administrasi Bisnis, 6(2), 1-7.

Ozdemir, I., \& Met, O. (2012). The expectations of Muslim religious customers in the lodging industry: The case of Turkey. In R. Zainal, Artinah; Radzi, Salleh Mohd; Hashim, Rahmat; Chik, Chemah Tamby; Abu (Ed.), Current issues in hospitality and tourism research and innovation (pp. 323-328). Taylor and Francis London.

Palupi, D. (2001). Mengikat Konsumen dengan Experiential Marketing. Swa Sembada, 24(8), 26-36.

Permana W, I. (2018). Penerapan Peraturan Pemerintah Tentang Hotel Syariah (Implementasi Permen Parekraf No. 2 Tahun 2014 tentang Hotel Syariah, studi kasus pada Hotel Sofyan Inn Specia Bandung). Jurnal Ilmiah TEDC, 12(3), 228-233.

Pine, B. J., \& Gilmore, J. H. (1998). Welcome to the experience economy. Harvard Business Review, 76(July-August), 97105.

Putri, Y. A., \& Astuti, S. R. T. (2012). Analisis Pengaruh Experiential Marketing terhadap Loyalitas Pelanggan Hotel "X" Semarang. Jurnal Ilmu Ekonomi ASET, 12(2), 191-199.

Razalli, M. R., Yusoff, R. Z., Roslan, M., \& Wahidar, M. (2013). A framework of halal certification practices for hotel 
industry. Asian Social Science, 9(11), 316-326.

Ridzuan, A. H. A., \& Zahari, M. S. M. (2012a). Customer awareness towards Syariah Compliant hotel. 2012 International Conference on Innovation Management and Technology Research, 124-128.

https://doi.org/10.1109/ICIMTR.2012.6 236373

Ridzuan, A. H. A., \& Zahari, M. S. M. (2012b). Dry hotel and Syariah compliant practices: Concepts, challenges and reality in Malaysia. 2012 International Conference On Innovation Management And Technology Research, 107-111.

https://doi.org/10.1109/ICIMTR.2012.6 236370

Saad, H. E., \& Ali, B. N. (2014). Shariacompliant hotels in Egypt: Concept and chanllenges. Advances in Hospitality and Tourism Research (AHTR), 2(1), 1-15.

Salleh, N. Z. M., Hamid, A. B. A., Hashim, N. H., \& Omain, S. Z. (2014). The practice of Shariah-compliant hotel in Malaysia. International Journal of Trade, Economics and Finance, 5(1), 26-30.

Samori, Z., \& Rahman, F. A. (2013). Establishing shariah compliant hotels in Malaysia: Identifying opportunities, exploring challenges. West East Journal of Social Sciences, 2(2), 95-108.

Samori, Z., \& Sabtu, N. (2014). Developing halal standard for Malaysian hotel industry: An exploratory study. Procedia-Social and Behavioral Sciences, 121(2014), 144-157. https://doi.org/10.1016/j.sbspro.2014.01 .1116 .

Schmitt, B. (1999). Experiential marketing. Journal of Marketing Management, 15(1-3), 53-67.

Shoemaker, S., \& Lewis, R. C. (1999). Customer loyalty: the future of hospitality marketing. International Journal of Hospitality Management, 18(4), 345-370.

Smilansky, S. (2017). Experiential marketing:
A practical guide to interactive brand experiences. Kogan Page Publishers.

Sofyan Hotel. (2019). Pesan Hotel di Cikini. https://sofyanhotel.com/sofyan-hotelcut-meutia-jakarta/

Sumarwan, U. (2011). Perilaku konsumen: Teori dan penerapannya dalam pemasaran. Bogor: Ghalia Indonesia.

Tsaur, S.-H., Chiu, Y.-T., \& Wang, C.-H. (2007). The visitors behavioral consequences of experiential marketing: An empirical study on Taipei Zoo. Journal of Travel \& Tourism Marketing, 21(1), 47-64.

Vargas-Sánchez, A., \& Moral-Moral, M. (2019). Halal tourism: state of the art. Tourism Review, 74(3), 385-399.

Widagdyo, K. G. (2015). Analisis pasar pariwisata halal indonesia. Tauhidinomics, 1(1), 73-80.

Wingett, F., \& Turnbull, S. (2017). Halal holidays: exploring expectations of Muslim-friendly holidays. Journal of Islamic Marketing, 8(4), 642-655.

Wu, C. H.-J., \& Liang, R.-D. (2009). Effect of experiential value on customer satisfaction with service encounters in luxury-hotel restaurants. International Journal of Hospitality Management, 28(4), 586-593.

Wu, H.-C., \& Li, T. (2017). A study of experiential quality, perceived value, heritage image, experiential satisfaction, and behavioral intentions for heritage tourists. Journal of Hospitality \& Tourism Research, 41(8), 904-944. 